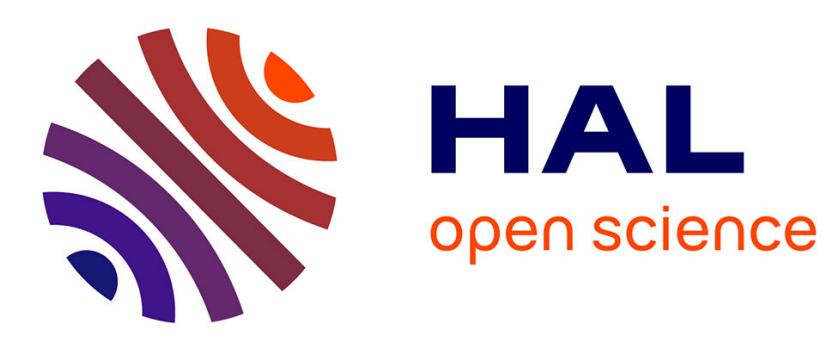

\title{
Inequality, unemployment, and poverty impacts of mitigation investment: evidence from the CDM in Brazil and implications for a post-2020 mechanism
}

\author{
David Grover, Swaroop Rao
}

\section{- To cite this version:}

David Grover, Swaroop Rao. Inequality, unemployment, and poverty impacts of mitigation investment: evidence from the CDM in Brazil and implications for a post-2020 mechanism. Climate Policy, 2020, 20 (5), pp.609-625. 10.1080/14693062.2020.1760773 . hal-03404189

\author{
HAL Id: hal-03404189 \\ https://hal.science/hal-03404189
}

Submitted on 26 Oct 2021

HAL is a multi-disciplinary open access archive for the deposit and dissemination of scientific research documents, whether they are published or not. The documents may come from teaching and research institutions in France or abroad, or from public or private research centers.
L'archive ouverte pluridisciplinaire HAL, est destinée au dépôt et à la diffusion de documents scientifiques de niveau recherche, publiés ou non, émanant des établissements d'enseignement et de recherche français ou étrangers, des laboratoires publics ou privés. 


\title{
Inequality, unemployment, and poverty impacts of mitigation investment: Evidence from the CDM in Brazil and implications for a post-2020 mechanism
}

\author{
David Grover ${ }^{1}$ \\ david.grover@grenoble-em.com \\ Swaroop Rao ${ }^{1,2}$ \\ swaroop.rao@grenoble-em.com
}

${ }^{1}$ Grenoble Ecole de Management, Univ Grenoble Alpes ComUE, 12 rue Pierre Sémard, 38000 Grenoble, France

${ }^{2}$ IREGE, Université Savoie Mont Blanc, 4 chemin de Bellevue, 74940 Annecy-leVieux, France

"This is an Accepted Manuscript version of the following article, accepted for publication in Climate Policy as David Grover \& Swaroop Rao (2020) Inequality, unemployment, and poverty impacts of mitigation investment: evidence from the CDM in Brazil and implications for a post-2020 mechanism, Climate Policy, 20:5, 609-625, DOI:

10.1080/14693062.2020.1760773. It is deposited under the terms of the Creative Commons Attribution-NonCommercial-NoDerivatives License (http://creativecommons.org/licenses/bync-nd/4.0/), which permits non-commercial re-use, distribution, and reproduction in any medium, provided the original work is properly cited, and is not altered, transformed, or built upon in any way." 


\begin{abstract}
Article 6 of the Paris Agreement provides for the creation of a successor to the Clean Development Mechanism (CDM), the parameters of which are currently being operationalised. This paper uses the broad literature on the relationship between general foreign direct investment (FDI) and inequality in FDI host countries to develop expectations about the likely impact of past and future international mitigation investment on inequality, unemployment and poverty outcomes. Using 2000 and 2010 census data for small geographic areas in Brazil, we compare the change in those outcomes in areas that experienced CDM project activity to the same in areas that did not, using a difference-in-difference approach. We find that areas with CDM project activity experienced improvements in those outcomes, which appear to be driven by project types that are associated with 'primary' sector activity. Including measurement and reporting procedures for these broader sustainable development outcomes in the rulebook of a post-2020 agreement could be favourable to the interests of both developed and developing countries.
\end{abstract}




\section{Key policy insights}

- We find evidence that CDM project activity drove reductions in inequality, poverty and unemployment in Brazilian regions from 2000 to 2010, relative to Brazilian regions where no CDM projects were present.

- This evidence fits with the idea that investment into primary and secondary sector activities (as opposed to tertiary sector ones) creates new demand for lower-skilled labour.

- Future supranational and national-level climate and emissions mitigation frameworks could take this into account at the design stage and specifically target inequality, unemployment, and poverty reduction through the new mechanism to be developed under Article 6 of the Paris Agreement.

\section{Keywords}

Foreign direct investment, income inequality, clean development mechanism (CDM), difference-in-difference method, Brazil 


\section{Introduction}

In Article 6 of the 2015 Paris Agreement, governments agreed to create a 'mechanism to contribute to the mitigation of greenhouse gas emissions and support sustainable development', and to adopt 'rules, modalities and procedures' to implement the mechanism. Legal, accounting, and technical challenges exist to operationalising such a mechanism for the post-2020 period (Unger, Greiner, \& Krämer, 2019). Developing country parties will be particularly concerned with the operationalisation of the 'sustainable development' objective in those commitments. However, the predecessor mechanism under the 1997 Kyoto Protocol, the Clean Development Mechanism (CDM or 'Mechanism' below), although it aimed to assist developing countries 'in achieving sustainable development', contained virtually no binding legal or economic provisions that would compel project developers and other actors to directly promote the aspects of sustainable development related to inequality, unemployment and poverty reduction in the design and operation of projects (Imran, Alam, \& Beaumont, 2014).

This paper takes as a starting point the numerous studies that have examined the impact of CDM projects on these aspects of sustainable development in developing countries (Boyd et al., 2009; Crowe, 2013; Olsen, 2007; Olsen \& Fenhann, 2012; Subbarao \& Lloyd, 2011; Sutter \& Parreño, 2007; Wittman \& Powell, 2015). Inequality, unemployment and poverty reduction are aspects of sustainable development, in addition to environmental protection (United Nations General Assembly, 1987). Some of these studies find that certain types of $\mathrm{CDM}$ projects associate with poverty reduction, in certain specific institutional and country contexts (Crowe, 2013; Du \& Takeuchi, 2018; Mori-Clement, 2019), but when they do, they tend to be 'only moderately successful' (Crowe, 2013: 58) and short-lived (Mori-Clement \& Bednar-Friedl, 2019). Taken as a whole, this body of research provides little evidence that CDM projects deliver strong, consistent and measurable reductions in inequality, unemployment or poverty.

This may not be surprising, given the lack of incentives actors involved in the process have to promote these outcomes. The closest would be the rules governing the CDM project approval process that require project developers to demonstrate 'environmental additionality' or 'financial additionality' (Paulsson, 2009; UNFCCC, 2012). To the knowledge of the authors, no method of demonstrating additionality accommodates the specific sustainable development outcomes of interest here. Article 6 of the Paris Agreement does appear to make stronger commitments to sustainable development as compared to the Kyoto Protocol, and 
commentators have seen this as a positive sign (Braden, Olsen, \& Verles, 2019; Carbon Market Watch, 2017). However, the exact definition of sustainable development and any specific implementation measures have not been finalised, since at the close of the COP25 in Madrid, negotiators had not managed to agree on a common rulebook on a potential successor mechanism, although some developing countries have underscored that sustainable development should be a 'national prerogative' (Allan, Antonich, Bansard, Luomi, \& Soubry, 2019).

In any case, the scale of investment associated with CDM projects during the period 2004 to 2016 certainly had the potential to promote sustainable development outcomes. As an exploratory exercise, we calculated the total volume of reported capital investment associated with CDM projects in the approximately 79 countries that received one, during that period, as published by the UN Climate Change Secretariat in its Project Activities and Programme of Activities (PA and PoA) database. ${ }^{1}$ The figure was USD 152 billion.

We then compared this to the total volume of foreign direct investment (FDI) received by those same countries during the same period, as published in the World Bank's World Development Indicators. ${ }^{2}$ This figure was USD 7,125 billion. This means that the ratio of CDM investment to FDI across all affected low- and middle-income countries together was approximately 1:47. Not all of the capital investment reported for CDM projects is newlyarrived foreign capital, of course, and there are also questions about the reliability of the reported CDM investment figures (discussed below). But this comparison underlines the point that the scale of CDM investment is not inconsiderable, and that the Mechanism has set a precedent for mobilising large volumes of private and mixed investment into low-cost mitigation in a way that lessens the risk and investment burden on the public sector (Zhang, 2001). However, despite these considerable reported capital investment volumes, their impact on the sustainable development outcomes of interest are poorly understood.

This paper addresses this gap by quantitatively testing the impact of CDM project activity on inequality, unemployment and poverty in Brazil. It extends prior research in several

\footnotetext{
${ }^{1}$ Available at https://cdm.unfccc.int/Projects/projsearch.html. As discussed in section 3, all projects that had not been awarded certified emission reduction (CER) credits were discarded. It is also important to note that the capital investment figures reported in the PA and PoA may be planned rather than actual investments. This is why those figures have been stated as 'reported' investment volumes 'associated' with CDM projects.

${ }^{2}$ The database defines FDI as the sum of equity capital, reinvestment of earnings, and other capital, and where ownership of ordinary shares of voting stock is $10 \%$ or greater.
} 
ways. First, it frames the question of the impact of CDM activity within the broader, arguably more influential, literature on the effect that general FDI has on these outcomes. In doing so it considers how the specific skill content required for various CDM project types may differently affect those outcomes. Second, it rigorously defines the presence and extent of CDM project activity using careful project selection criteria, measured as the number of certified emission reduction (CER) credits issued to actual, verified projects.

Section 2 situates the CDM within the literature on how and why FDI may affect inequality. Section 3 describes the data and methods used in the tests. Section 4 presents the findings. Section 5 discusses the findings and draws study conclusions. Section 6 gives policy implications.

\section{Literature review}

This section is organized as follows. It defines FDI and describes the channels through which FDI is thought to influence between-country and within-country inequality. It then elaborates recent research on how the impact of FDI seems to vary according to the sector it flows into, and the nature of the skills for which it creates demand. Within this debate it positions the literature evaluating the impact of CDM projects on inequality, unemployment and poverty. Testable research questions are posed.

\subsection{FDI and inequality}

FDI can be defined as the flow across international borders of firm-specific capital, including financial capital, proprietary production technologies, brands and trademarks, and organizational and/or managerial practices (Pandya, 2014). Many of the mitigation activities that have occurred under the CDM fit this definition (Niederberger \& Saner, 2005), some albeit imperfectly. FDI in general is widely held to facilitate economic development and growth in the countries and sub-national territories that receive it (Almfrajiab \& Almsafir, 2014; Herzer, 2008; Makki \& Somwaru, 2004). Theory and evidence shows that these effects occur through various channels, including: the transfer to the host country of modern production technologies and managerial practices that raise the productivity of workers and firms (Alfaro, Kalemliozcan, \& Sayek, 2009), the production of goods and services for consumption in the host country that were not previously available or available only at low quality or high cost 
(UNCTAD, 2011); and the additional tax revenues that governments raise from FDI-related production activities that then get invested in social and economic development programmes (Tsai, 1995).

However, while there is a degree of consensus that FDI facilitates economic growth and development, there is active scientific debate around whether FDI raises or lowers the level of income inequality among nationals in recipient countries (Basu \& Guariglia, 2007; Bermejo Carbonell \& Werner, 2018; Iamsiraroj, 2016). Concern over the inequality effects of FDI flowing to developing countries began to gather in the mid-1990s around the time that free trade agreements such as NAFTA were being implemented (Suanes, 2016). To the knowledge of the authors, few insights from this literature are currently reflected in the CDM policy evaluation literature or in the post-2020 mechanism design process.

\subsection{Between- and within-country inequality}

One strand of this literature examines the impact of FDI on between-country inequality. Standard models of international production, such as the Heckscher-Ohlin framework, predict that countries produce goods and services that use the factors of production in which they are abundant. This framework predicts that FDI flows to countries where the necessary production factors are abundant, and inexpensive, and once it arrives there, benefits the abundant production factor (Willem Te Velde, 2003). For example, if FDI flows from a high-income country where labour is expensive to a low-income country where labour is inexpensive, labour in the low-income country should benefit, and the level of wage inequality between the countries should fall (Herzer, Hühne, \& Nunnenkamp, 2014). In the same way, the return to capital that already existed in the FDI-receiving country should fall relative to that in the FDIsending country, as the new inflow of capital into the receiving country should dilute the returns previously achieved by capital holders (Pandya, 2014).

Unfortunately the standard model does not account well for the impact that FDI has on within-country inequality, which has been the focus of the recent FDI literature and of the few quantitative CDM impact studies (Mori-Clement, 2019; Mori-Clement \& Bednar-Friedl, 2019). When the focus is on the within-country impacts of FDI, the literature tends to focus on which types of workers benefit from the employment FDI creates. For example, Im \& Mclaren (2015) propose that FDI raises demand for skilled labour in the host country and hence the wages of skilled workers, which in turn drives a wedge between the wages of skilled and unskilled workers. In the account of Feenstra \& Hanson (1996), FDI increases inequality 
because even the most basic production activities of multi-national companies raise demand for relatively skilled workers, given that a minimum skill quality threshold is needed to produce goods that are part of a global production chain. In an empirical study, Chen, Ge, \& Lai (2011) found that FDI in China increases inter-enterprise wage inequality because foreign companies pay a wage premium to the local workers they employ.

Numerous empirical studies have found that FDI leads to greater within-country inequality, even if the relationship is not directly attributed to the nature of the employment created. Jaumotte, Lall and Papageorgiou (2013) studied a panel of countries during the period 1981-2003 and found that FDI was a leading explanation for rising income inequality in certain Asian and Latin American countries. Basu \& Guariglia (2007) examined a panel of 119 developing countries during the period 1970-1999 and found that FDI increased both economic growth and inequality. In another panel study of country-years, Tsai (1995) found that FDI increased inequality particularly in Southeast Asian countries. In a study of 88 developing countries between 1980 and 1997, Kentor (2001) found that 'foreign capital dependence' raises income inequality.

\subsection{FDI and skill demand}

The most recent work on the FDI-inequality relationship has tried to move beyond treating FDI as uniform, towards examining how specific types of FDI affect inequality. The emerging hypothesis in this literature is that when FDI flows into the services/tertiary sector in a host-country, inequality rises because skilled workers tend to work in this sector and so benefit from greater demand for their skills in the form of higher wages. Unskilled workers do not benefit. However, when FDI flows into the primary sector and perhaps also the manufacturing sector, inequality falls, because these sectors employ a greater proportion of unskilled workers (Jensen \& Rosas, 2007; Raveh \& Reshef, 2016; Suanes, 2016).

Recent empirical studies tend generally to support this hypothesis. In a panel study of middle-income countries (1989-2010), Bogliaccini \& Egan (2017) found that FDI into the services/tertiary sector associates more strongly with inequality than FDI into the manufacturing or primary sector. Raveh \& Reshef (2016) found that 'general' capital imports to developing countries do not increase wage inequality between skilled and unskilled workers, but that imports of capital for performing R\&D and other tasks related to innovation, do. Jensen \& Rosas (2007) found that the Mexican states that attracted more FDI (which was heavily concentrated in manufacturing) during the 1990-2000 period experienced lower inequality 
relative to those that attracted less FDI. Other research on the Mexican case finds that the relative demand for skilled labour has increased in the context of rising FDI under NAFTA (Hanson, 2003; Herzer, Hühne \& Nunnenkamp., 2014).

The prior literature evaluating the impact of the CDM on inequality, unemployment and poverty can now be positioned within this skills- and employment-related perspective on why FDI might increase inequality in some instances and decrease it in others. Little of the $\mathrm{CDM}$ evaluation literature has been guided by this perspective to date.

\subsection{Inequality and CDM activity}

In reviews of the literature on the effects of CDM projects on poverty alleviation, Dirix, Peeters, \& Sterckx (2016) and Olsen (2007) concluded that there is little evidence that CDM projects have substantially helped reduce poverty. Sirohi (2007), in a mixed methods study involving 65 projects found that the CDM projects in India that benefit low-income groups tend to be located in rural areas. Crowe (2013), in a more qualitative and later study of 114 CDM projects worldwide, including projects with add-on standards (with registration dates in 2010 and 2011), found that regular CDM projects are only 'moderately' successful at delivering pro-poor benefits and that projects that do are characterized by the use of add-on project standards, a high degree of stakeholder participation, and the involvement of not-forprofit and government entities as project developers. Du \& Takeuchi (2019) studied the effect of CDM projects on income and employment in rural communities in China, using a differencein-difference method. They found that biomass projects contributed to income and employment generation.

In the Brazilian context specifically, Mori-Clement \& Bednar-Friedl (2019) found that the effect of CDM projects on local employment in Brazil was mixed, and when present, small and transitory. Mori-Clement (2019) tested the impact of CDM projects on inequality, employment, and poverty outcomes in Brazil between 2000 and 2010, much like the present study does. Mori-Clement (2019) also used a difference-in-difference approach and tried to improve the comparability of places that did and not did receive a CDM project through propensity score matching. The spatial unit used was the municipality (whereas, in the present study, it is the micro-region, which is larger). Mori-Clement (2019) found that inequality fell by $2 \%$ in the municipalities that had a CDM hydroelectric project relative to the municipalities that did not. 
Our research builds on all this prior literature in several ways. First, it frames CDM investment activity within the broader literature on the inequality impacts of FDI, and proposes an explicit channel by which FDI may be inequality-reducing. Second, it operationalises the presence and extent of regional CDM project activity in an empirical model more rigorously than prior quantitative studies to our knowledge. Third, it derives from the findings recommendations for concretely including sustainable development outcomes in the design of a post-2020 investment mechanism.

Within this FDI-and-inequality framework, we now turn to the empirical analysis of CDM project activity in Brazil. The first research question asks how CDM projects have influenced inequality, unemployment and poverty in the places that hosted them. The second question asks how these impacts vary across CDM project types.

\section{Data and methods}

\subsection{Empirical context}

Brazil has been a major recipient of FDI in the last decades and the largest recipient in South America (Suanes, 2016). World Development Indicators data from the World Bank show that Brazil received approximately USD 278 billion in net FDI during the period 2003 to 2010 in total. During the same period, UNFCCC figures show that the reported total investment volume associated with registered CDM projects in Brazil was approximately USD 7.5 billion. This makes a ratio of 1 to 17 .

Brazilian society is also characterised by a high level of income inequality and there are many explanations for this (Medeiros, 2016; Silveira Neto \& Azzoni, 2011). In the context of the current research, it is relevant to point out that much of the FDI to Brazil in the last decade has flowed to the services/tertiary sector. The Central Bank of Brazil reports that in 2005 , about $63 \%$ of all FDI to Brazil by volume went to the services/tertiary sector, while only $3.6 \%$ went to the primary sector, and the rest to manufacturing (Banco Central do Brasil, 2005). The large proportion of FDI that has gone to the services/tertiary sector could be one reason why some studies have found that recent FDI into Brazil and other countries in the region has tended to increase inequality (Suanes, 2016).

Focusing on Brazil, our empirical approach tests how the level of inequality, unemployment and poverty responded over time to CDM activity. Implicitly, the approach 
evaluates unemployment reduction as the main channel through which income inequality and poverty might be affected. Any of these outcomes might be affected by the number of jobs created by CDM activity. The approach also tests how the relationship between these outcomes and CDM project activity is moderated by the type of CDM project (biomass, hydro, landfill, methane, wind, other). Although it is not possible to directly observe the skills involved in the jobs created, it is hypothesized that the skills required to do 'CDM jobs' varies by project type. This might mean that only project types that create low-skill jobs impact the outcomes of interest. This would be the case if unemployment concentrates at the lower end of the skill spectrum, for example.

\subsection{Data}

We constructed a panel dataset of small geographic areas. The areas are Brazilian micro-regions, of which there are 558 (also referred to as 'regions' from here on), observed once in the year 2000 and once in the year 2010. The dependent variables measuring inequality (Theil index, Theil index for work-derived income, Gini index) and related indicators (percent of individuals economically inactive, percent of individuals in poverty, percent of income derived from work) were obtained from the UNDP's Human Development Atlas (which uses Brazilian census data).

The independent variable relates to the extent of CDM project activity in each region. In the regressions it is measured by the number of CER credits issued to all projects in the region.

To select the projects for this variable, we started with the full record of projects given in the PA and PoA database (which is publicly available on the UN Climate Change Secretariat website - see footnote 1). As of December 2019, there were 760 project records for Brazil. The earliest project appeared in November 2004 and the latest in July 2019. Since the dependent variables are observed in 2000 and 2010 only, we used only the projects where the start date of the first CER credit issuance period was in or before $2010 .^{3}$ There were 147 such projects.

\footnotetext{
${ }^{3}$ As a robustness check, we also tested a version of the variable constructed from projects that were actually issued CER credits in or before 2010 . This is a slightly more restrictive selection criteria, yielding 101 projects. The test results were comparable to the main results as can be seen from Table 7 in the appendix.
} 
Using the start date of the first CER credit issuance period to select projects also maximised the likelihood that the projects included in the independent variable are actual, operational projects (whose effects on the outcomes might be detected), as opposed to project plans. ${ }^{4}$ The CDM project approval process works, broadly, as follows. First, a project developer registers a project with the CDM Executive Committee. Then, after an external verification, the CDM Executive Committee decides over multiple review stages if the project satisfies all of the necessary requirements to be issued CER credits, including demonstrating 'additionality'. 5 Then the CDM Executive Committee issues CER credits to the project if all of the requirements have been met. Our aim in selecting only the projects that have been issued CER credits is to maximise the likelihood that the variable in the empirical tests is measuring actual on-the-ground project activity.

The PA and PoA database does not provide information on projects' detailed geographic location. This information was obtained from sections A.4.1.3 and A.4.1.4 of each project's Project Design Document (PDD). The municipality or municipalities that the project was located in were recorded and collapsed into micro-regions (there are about 10

\footnotetext{
${ }^{4} \mathrm{We}$ are grateful to an anonymous reviewer for pointing this out and constructively suggesting remedies that we have adopted here.

${ }^{5}$ In order for a CDM project to be issued CER credits, the project developer must demonstrate that the proposed project will result in an 'additional' outcome, relative to a counterfactual baseline where the project did not exist (UNFCCC, 2012). Under the Mechanism, the meaning of 'additionality' and the methods used to assess it are flexible (Cames et al., 2016). Additionality need not be only 'environmental' in the sense of avoided GHG emissions. A project can also fulfil the requirement by demonstrating 'financial additionality' or by demonstrating a combination of both environmental and financial additionality (Paulsson, 2009). Some evidence suggests that the 'additional' outcome claimed by projects might not always be realized, even when the bureaucratic standard for demonstrating additionality is satisfied (Michaelowa \& Purohit, 2007). For example, Zhang \& Wang (2011) found that the emission reductions associated with CDM projects in Chinese prefectures would have happened anyway. This implies that those reductions cannot be causally attributed to the CDM. Several of the quantitative contributions to the CDM impact literature have remained agnostic on what additionality means for testing causal connections between CDM projects and the claimed outcomes (Du \& Takeuchi, 2019; Mori-Clement, 2019; Mori-Clement \& BednarFried1, 2019). Additionality is a programme design issue that goes beyond the scope of this research but does bear on the possibility to independently evaluate the effects of the Mechanism, or its successor, econometrically. The limitations implied by additionality for this research are discussed in section 5.
} 
municipalities per micro-region). ${ }^{6}$ PDDs are the only source of systematic information about projects' detailed geographic location to the knowledge of the authors. It is fully possible that the actual project design, including its geographic location, expanded or contracted or moved during the credit application process. This is a well-known limitation of PDDs (Crowe, 2013). We treat this as measurement error. The only information obtained from the PDDs is project geographic location; all other data came from the PA and PoA database.

Other independent variables were used to account for nuisance heterogeneity in the regressions. Data on the level of GDP in each region-year were obtained from the Brazilian Institute of Geography and Statistics (IBGE). Data on the level of transfers to each region-year under the Brazilian Federal social welfare programme Bolsa Familia were obtained from the Brazilian Ministry of Social Development (MDS). Data on the stock of FDI in each state-year were obtained from the annual census of foreign investment of the Central Bank of Brazil (the bank does not gather or publish FDI data below the level of the state). The remaining control variables (the percent of the population that is rural, the illiteracy rate, and the electrification rate) come from the same source as the dependent variables, the UNDP's Human Development Atlas.

\subsection{Descriptive analysis}

Tables 1 and 2 describe the dependent and independent variables used in the regressions. There are 1,116 observations for all variables. Descriptive statistics are given as linear values but all of the dependent variables and some of the independent variables are logged in the regressions. All variables vary in dimensions $t$ (year) and $i$ (region) except for FDI_state which varies by $t$ and not by region but by state (Brazilian federal units, of which there are 27). The independent variable that tests the effect of CDM project activity on the outcomes of interest is the interaction of Year_2010 and CDM_credits. CDM_credits is the number of credits issued to all projects in the region and thus measures both the presence and scale of CDM activity.

\footnotetext{
${ }^{6}$ The main reason for structuring the data as a panel of micro-regions, and not municipalities, was that many projects spread across multiple municipalities. Approximately $39 \%$ of the projects we examined spread over two or more municipalities, and $12 \%$ spread over more than five. Collapsing data to the micro-region level minimises the risk of falsely assuming that a CDM project exists in an area when in fact it does not.
} 
Table 1: Dependent variable descriptive statistics

\begin{tabular}{|c|c|c|c|c|}
\hline Variable & Description & Min & Max & Mean \\
\hline Theil $_{i t}$ & Theil index of income inequality (scale $0-100$ ) & 24.4 & 93.8 & 49.9 \\
\hline Theil_work it $_{\text {Th }}$ & Theil index, work-derived income only (scale $0-100$ ) & 22.6 & 87.0 & 43.7 \\
\hline Gini $_{\text {it }}$ & Gini index of inequality (scale $0-100$ ) & 36.9 & 71.5 & 53.0 \\
\hline Unemployment ${ }_{i t}$ & $\%$ of individuals economically inactive & 0.9 & 28.5 & 8.7 \\
\hline Poverty $_{i t}$ & $\%$ of individuals in poverty & 1.0 & 81.6 & 31.2 \\
\hline Income_work ${ }_{i t}$ & $\%$ of income work-derived & 44.6 & 95.5 & 72.9 \\
\hline
\end{tabular}

Note: 1,116 observations for all variables. In the regressions, all dependent variables are estimated in logs.

Table 2: Independent variable descriptive statistics

\begin{tabular}{|c|c|c|c|c|c|}
\hline Variable & Description & Min & Max & Median & $\begin{array}{l}\text { Standard } \\
\text { Deviation }\end{array}$ \\
\hline Year_2010t & Year $=2010$ & 0 & 1 & 0.5 & 0.5 \\
\hline$C D M$ credits $i t$ & \# credits issued to CDM projects & 0 & $67,699,487.3$ & $236,239.7$ & $2,927,665.9$ \\
\hline CDM_credits_biomass ${ }_{i t}$ & \# credits issued to biomass projects & 0 & $2,514,403$ & 17,085 & $141,111.6$ \\
\hline CDM_credits_hydro ${ }_{i t}$ & \# credits issued to hydro projects & 0 & $1,823,686.5$ & $19,428.3$ & $124,959.7$ \\
\hline CDM_credits_landfill $l_{i t}$ & \# credits issued to landfill projects & 0 & $10,023,403$ & $61,826.6$ & $601,086.3$ \\
\hline CDM_credits_methane $i t$ & \# credits issued to methane projects & 0 & 478,609 & $8,151.8$ & $39,474.7$ \\
\hline CDM_credits_wind $d_{i t}$ & \# credits issued to wind projects & 0 & 292,505 & 614.8 & $12,557.1$ \\
\hline$C D M$ credits other ${ }_{i t}$ & \# credits issued to other projects & 0 & $63,118,494$ & $129,133.2$ & $2,674,747.1$ \\
\hline GDP growth & GDP growth rate from previous year & 0.7 & 16 & 2.6 & 1.1 \\
\hline Bolsa_spending ${ }_{i t}$ & Bolsa Familia transfers, 000s USD & 0 & $23,969.5$ & 808.8 & $1,414.8$ \\
\hline FDI_state $i t$ & Level of FDI in state, 000 s USD & 188.2 & $297,126,615.1$ & $31,082,101.7$ & $68,980,448.7$ \\
\hline Population $_{i t}$ & Population & 2,629 & $13,793,504$ & 341,842 & $877,681.5$ \\
\hline Rural population ${ }_{i t}$ & $\%$ of population rural & 0 & 79.3 & 30.1 & 17.4 \\
\hline Iliteracy rate $_{i t}$ & $\%$ of population 25 years or older illiterate & 3.2 & 61.5 & 24.6 & 13.8 \\
\hline Electrification $_{i t}$ & $\%$ of population in dwellings with electricity & 33.8 & 100 & 91.2 & 12.5 \\
\hline
\end{tabular}


The distinction between the Theil and Gini indexes of inequality in Table 1 is worth elaborating. The Theil index measures inequality in the per capita distribution of income in the micro-region and excludes individuals with zero income from the measure. Theil captures how the distribution of income across households differs from the distribution of the population across households. When the distribution of the population across households is the same as the distribution of income, the Theil value is zero (no inequality) (World Bank, 2005). By contrast, the Gini index measures the distribution of income across households in the microregion only, such that when the income is equally distributed across households, there is no inequality and the value is zero. Thus the main difference is that Gini does not account for the distribution of the population across households.

Figure 1 shows the distribution of ordinary FDI across Brazilian states and compares this with the distribution of issued CDM credits for the 147 projects. States which did not have a CDM project are excluded. For the states with a CDM project, the distribution of credits broadly approximates the distribution of ordinary FDI.

\section{Figure 1: Distribution of FDI and CDM credits by Brazilian state}

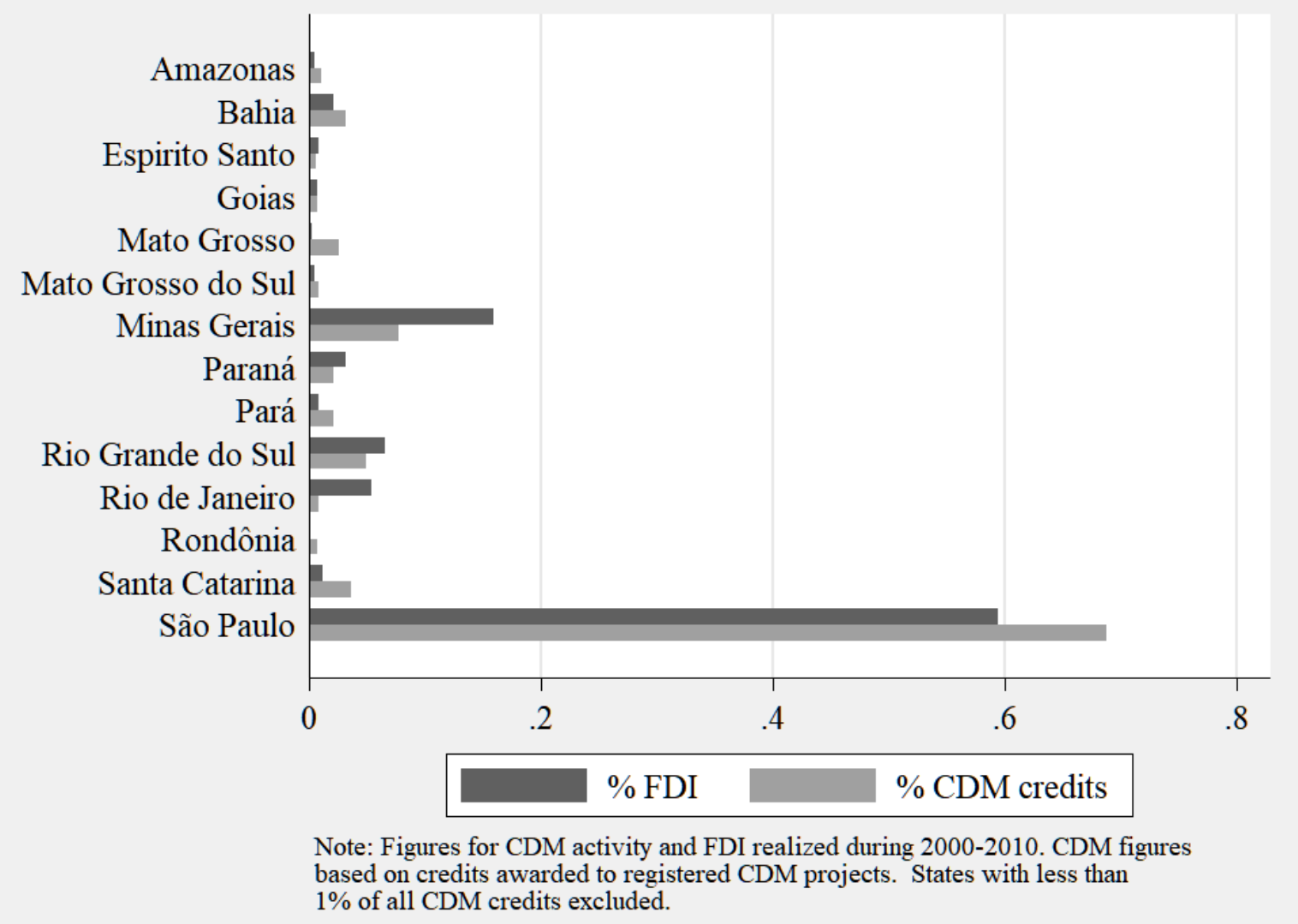


Figure 2 shows the micro-regions that had at least one CDM project prior to 2010 . CDM projects concentrate in the more industrialized south and southeast of Brazil and in the central-west region where agricultural output is strong.

\section{Figure 2: Distribution of CDM projects across micro-regions}

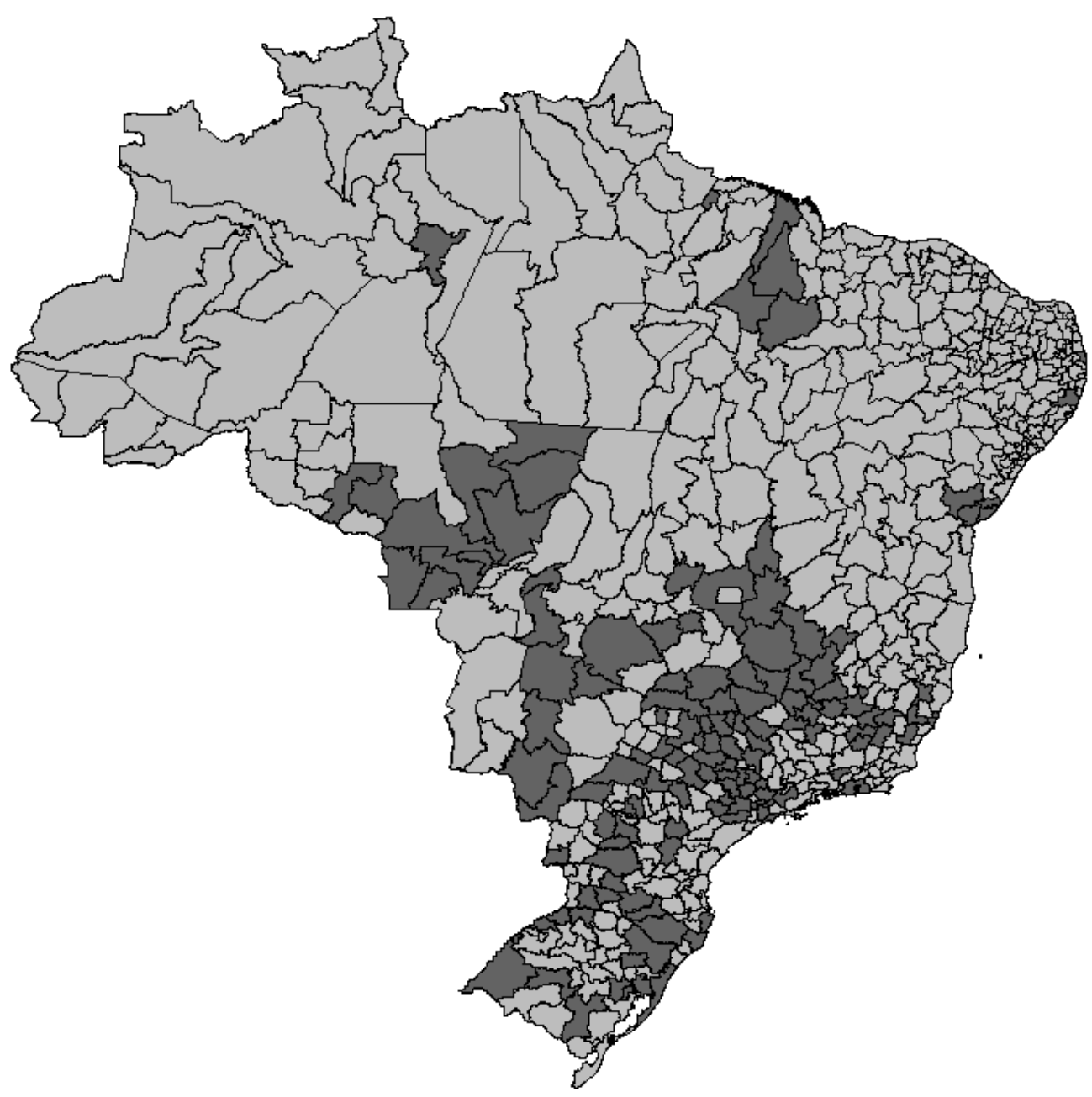

Note: Micro-regions in dark grey received at least one CDM project in or before 2010. The projects in question are only those that were issued CER credits in or before 2010.

To give a sense of the scale of a CDM project in the context of the economic activity of a micro-region, the mean level of reported investment associated with these CDM projects is USD 30 million. The level of reported investment for the smallest project was USD 58,000 and for the largest USD 406 million. The mean annual GDP for the average micro-region was about USD 1.2 billion. Thus, the average CDM project amounts to around $2.5 \%$ of the average micro-region's GDP. Of the 558 micro-regions, 158 (28.3\%) had a CDM project (or part of one, since some projects spread across several regions) by 2010 . 
On a project-count basis, $27.8 \%$ of the CDM projects included in the independent variables are categorized in the PA and PoA database as methane avoidance projects $(3.4 \%$ of CER credits), $23.8 \%$ as biomass energy projects (7.2\% of CER credits), $21.1 \%$ as hydro projects (8.2\% of CER credits), $14.3 \%$ as landfill projects (26.1\% of CER credits), and the rest as related to fossil fuel switching, $\mathrm{N}_{2} \mathrm{O}$, wind, reforestation and other activities.

Also at project-level, the simple correlation coefficient between log CER credits issued and log capital investment is 0.11 . This figure pertains only to the 83 projects with capital investment data (for the other 64 projects, the data are missing).

\subsection{Regression model}

The research design compares the change in the level of the dependent variable in the regions that had a CDM project to the same in the regions that did not. This difference-indifference (DD) approach is well suited to policy evaluation research because it compares outcomes between a treated group and a control group over time in a non-experimental setting using observational data (Khandker, Koolwal, \& Samad (2010); Wooldridge (2012), also see Du \& Takeuchi (2019) and Mori-Clement (2019) for DD applications in this specific policy context). The test is operationalized in the following empirical model,

$$
\begin{aligned}
\text { Theil }_{i t}=\alpha+ & \beta_{1}(\text { CDM_credits } \\
i & \left.\times \text { Year_2010 }_{t}\right)+\beta_{2}\left(\text { CDM_credits }_{i}\right) \\
& +\beta_{3}\left(\text { Year_2010 }_{t}\right)+\boldsymbol{X}_{i t}+\varepsilon_{i t}
\end{aligned}
$$

where subscript $i$ denotes the regions and $t$ denotes the years 2000 and 2010. Theil is the Theil index measuring the level of inequality in the region-year (or one of the other five dependent variables). CDM_credits is the number of credits issued to all projects in the region. ${ }^{7}$ Year_2010 is a dummy variable that takes a value of 1 for the year 2010, the post-treatment period, and 0 otherwise. We are interested in coefficient $\beta_{l}$ on the interaction of those variables. Coefficient $\beta_{1}$ estimates how the level of inequality in the areas that had CDM project activity

\footnotetext{
${ }^{7}$ Five other measures of the extent of CDM project activity were also tested: the level of investment, the number of megawatts installed, the quantity of GHG reductions claimed, the number of fractional projects, and the binary presence of a project. The number of CER credits issued was chosen because it is a continuous and so more granular measure, because it has no missing values, and because it is most likely to reflect real material projects on the ground (in the sense of the discussion in section 3.2).
} 
changed between 2000 and 2010, relative to the same in the control group. $\alpha$ is a constant, $X$ denotes control variables, and $\varepsilon$ is an error term.

The CDM_credits variable is logged in all estimations, and since all dependent variables are also logged in all estimations, coefficient $\beta_{1}$ can be interpreted as an elasticity, e.g. the predicted average $\%$ change in the level of the dependent variable for a $1 \%$ change in the number of credits. This same interpretation pertains to the second set of tests of the effect of project type. In those tests, six separate $C D M$ _credit variables are included, each measuring the number of credits issued to CDM projects of each type in the region (CDM_credits_biomass for example). Each is separately interacted with Year_2010.

One issue that could bias the result of our experiment design is endogenous treatment assignment. This relates to the process by which CDM projects locate in regions. The location of projects in regions is likely to be non-random. Non-random location is a problem if unobserved factors exist that affect both the location of projects and the outcome variable. For example, rapid economic growth in an area could affect the level of inequality but also signal to project developers an attractive investment opportunity (if more counter-factual emissions results in more CERs being issued to the project for example).

The DD approach mitigates this problem by comparing the change in the outcome in treated areas to the same in control areas, thus estimating the CDM effect relative to an untreated control group. We include seven time-varying controls to account for factors that could associate with both the outcome variable and the location of CDM projects.

First, Brazil experienced rapid economic growth for much of the 2000-2010 period. Depending on who these gains accrued to and in which areas, the control and treatment group areas might have been differently affected. The growth in the level of GDP in each area-year accounts for this.

Second, the elected government in Brazil during the period consolidated various federal social welfare programmes and increased spending under them (Schwartzman, 2003). Among the most significant was the Bolsa Familia which made small transfers to qualifying poor families (Wetzel, 2013). The level of spending in each area-year under the Bolsa Familia programme accounts for this factor. ${ }^{8}$

Third, general FDI that had little to do with CDM could have differently affected inequality levels over time in the control and treatment groups. The Central Bank of Brazil

\footnotetext{
${ }^{8}$ The earliest year Bolsa data were available for was 2004. We used the 2004 data for Bolsa as a proxy for the level of social welfare support in each area in the year 2000.
} 
does not report FDI figures for geographic units smaller than Federal units (state). The stock of FDI in each state, in 2000 and 2010, accounts for this.

Fourth, CDM project developers might have favoured regions where the population was growing, since these regions would also have had high expected emissions growth, all else being equal. Higher expected emissions growth could mean a larger volume of abatable emissions and so the possibility for more reductions to be achieved and CERs to be issued. The population level in each area-year is included.

Fifth, two additional variables were added reflecting the socioeconomic character of the regions, namely the illiteracy rate for individuals 25 years or older, and the percent of the population in the region residing in rural areas.

Sixth, another large policy initiative during the period was the Federal government-led Luz para todos ('Light for All') rural electrification programme. The effect of the programme is accounted for by a variable measuring the percent of the population living in a dwelling with electricity.

Finally, some DD designs include individual fixed effects to account for the timeinvariant characteristics of individuals, in this case regions (Lechner, Rodriguez-Planas, \& Kranz, 2016). We do not include individual fixed effects in the main estimates for two reasons (although we include them in the robustness checks). First, the main threat to the validity of the test design is omitted factors that are time-varying and we are able to account for these with the control variables above. Second, the fact that DD compares the difference in groups over two time periods can be seen as equivalent to first-differencing the outcome variable, which achieves the same result as estimating the model with individual fixed effects.

\section{Results}

Table 3 shows the first set of results, which test the effect of CDM project activity in general. These estimates imply that a $1 \%$ increase in the number of CERs issued associates with a decrease in the level of Theil inequality in CDM regions of approximately $1.1 \%$ on average, compared to regions with zero credits (projects). A similar effect in magnitude and direction is found for the other inequality indicators Theil_work and Gini, although the magnitude of Gini is substantially smaller (see the explanation for the differences between the two inequality measures in section 3.3). The results in Table 3 also imply that a $1 \%$ increase in the number of credits associates with a $1.3 \%$ decrease in Unemployment in CDM regions on 
average, and a $2.2 \%$ decrease in Poverty in CDM regions on average. No significant impact is found on Income_work, the proportion of income derived from work. 
Table 3: General results

\begin{tabular}{|c|c|c|c|c|c|c|}
\hline & Theil & Theil_work & Gini & Unemployment & Poverty & Income_work \\
\hline \multirow[t]{2}{*}{ CDM_credits $x$ Year_2010 } & $-0.011^{* * *}$ & $-0.012^{* * *}$ & $-0.004^{* * *}$ & $-0.013^{* * *}$ & $-0.022^{* * *}$ & -0.000 \\
\hline & $(-6.01)$ & $(-5.82)$ & $(-4.51)$ & $(-3.41)$ & $(-5.81)$ & $(-0.18)$ \\
\hline \multirow[t]{2}{*}{ CDM_credits } & $0.006^{* * *}$ & $0.007^{* * *}$ & $0.002^{* *}$ & 0.005 & $0.006^{*}$ & $0.003^{* * *}$ \\
\hline & $(3.86)$ & (4.14) & (3.22) & (1.70) & (2.49) & $(4.70)$ \\
\hline \multirow[t]{2}{*}{ Year 2010} & $-0.189^{* * *}$ & $-0.237^{* * *}$ & $-0.115^{* * *}$ & $-0.631^{* * *}$ & $-0.960^{* * *}$ & -0.023 \\
\hline & $(-7.69)$ & $(-8.42)$ & $(-10.23)$ & $(-10.88)$ & $(-19.72)$ & $(-1.90)$ \\
\hline \multirow[t]{2}{*}{ GDP_growth } & 0.004 & -0.009 & 0.002 & $0.046^{* * *}$ & $0.019^{*}$ & $0.009^{* * *}$ \\
\hline & $(0.97)$ & $(-1.73)$ & $(1.02)$ & $(5.06)$ & $(2.43)$ & $(4.20)$ \\
\hline \multirow[t]{2}{*}{ Bolsa_spending } & $0.113^{* * *}$ & $0.053^{* *}$ & $0.050^{* * *}$ & $0.239^{* * *}$ & $0.539^{* * *}$ & $-0.073^{* * *}$ \\
\hline & $(6.59)$ & $(2.62)$ & $(6.41)$ & $(5.21)$ & $(14.66)$ & $(-8.84)$ \\
\hline \multirow[t]{2}{*}{ FDI_state } & $-0.021^{* * *}$ & $-0.014^{* * *}$ & $-0.010^{* * *}$ & $0.023^{* * *}$ & $-0.040^{* * * *}$ & $-0.012^{* * *}$ \\
\hline & $(-7.08)$ & $(-5.01)$ & $(-7.01)$ & (3.77) & $(-8.87)$ & $(-9.48)$ \\
\hline \multirow[t]{2}{*}{ Population } & $-0.106^{* * *}$ & -0.039 & $-0.050^{* * *}$ & $-0.259^{* * *}$ & $-0.459^{* * *}$ & $0.062^{* * *}$ \\
\hline & $(-5.64)$ & $(-1.76)$ & $(-5.76)$ & $(-5.46)$ & $(-11.84)$ & $(6.78)$ \\
\hline \multirow[t]{2}{*}{ Rural_population } & -0.005 & $0.050^{* * *}$ & -0.005 & $-0.341^{* * * *}$ & $0.093^{* * *}$ & -0.003 \\
\hline & $(-0.59)$ & $(5.28)$ & $(-1.27)$ & $(-13.78)$ & $(5.48)$ & $(-0.70)$ \\
\hline \multirow{2}{*}{ Iliteracy_rate } & -0.025 & -0.037 & -0.005 & $0.280^{* * *}$ & $0.414^{* * *}$ & $-0.103^{* * *}$ \\
\hline & $(-1.31)$ & $(-1.72)$ & $(-0.61)$ & $(6.50)$ & $(10.98)$ & $(-11.20)$ \\
\hline \multirow[t]{2}{*}{ Electrification } & $-0.116^{* *}$ & $0.116^{* *}$ & $-0.164^{* * *}$ & 0.077 & $-0.201^{* *}$ & $-0.194^{* * *}$ \\
\hline & $(-3.09)$ & $(2.73)$ & $(-7.94)$ & $(0.75)$ & $(-3.03)$ & $(-8.05)$ \\
\hline Obs. & 1116 & 1116 & 1116 & 1116 & 1116 & 1116 \\
\hline R2 & 0.40 & 0.34 & 0.56 & 0.53 & 0.89 & 0.59 \\
\hline AIC & -1086.8 & -794.1 & -2800.0 & 741.4 & 337.5 & -2273.5 \\
\hline DV mean & 3.89 & 3.76 & 3.96 & 2.12 & 3.23 & 4.26 \\
\hline
\end{tabular}

Note: All dependent variables are in logs. All independent variables are in logs except Year_2010 and GDP_growth. Estimation by OLS. T-scores in parentheses.

Heteroskedasticity-robust errors. Constant omitted for presentation. 
Table 4 shows the second set of estimates. These pertain to the moderating effect of CDM project type on the same outcomes. The first set of results shows the estimates for all of the control variables, for explicitness, but these are omitted from Table 4 for presentational purposes (they remain in the underlying models). The estimates for the project type-specific model imply that methane, hydro, and to a lesser extent biomass projects associate with reduced inequality. For example, a $1 \%$ increase in methane project credits associates with an average decrease in Theil of 1.2\%, an average decrease in Theil_work of $1.3 \%$, and an average decrease in Gini of $0.04 \%$. Methane projects also associate significantly with a reduction in Poverty, biomass projects with a reduction in Unemployment and Poverty, and hydro projects with a reduction in Poverty. There is also some evidence that wind projects associate with a reduction in Unemployment and a decrease in Income_work (opposite to the direction expected). 
Table 4: Project type-specific results

\begin{tabular}{|c|c|c|c|c|c|c|}
\hline & Theil & Theil work & Gini & Unemployment & Poverty & Income work \\
\hline \multirow{2}{*}{ CDM_credits_biomass $x$ Year_2010 } & -0.006 & $-0.007^{*}$ & -0.002 & $-0.014^{*}$ & $-0.016^{*}$ & 0.000 \\
\hline & $(-1.75)$ & $(-2.09)$ & $(-1.53)$ & $(-2.50)$ & $(-2.08)$ & $(0.25)$ \\
\hline \multirow[t]{2}{*}{ CDM_credits_hydrox Year_2010 } & $-0.008^{*}$ & $-0.008^{*}$ & -0.003 & -0.003 & $-0.016^{*}$ & -0.000 \\
\hline & $(-2.39)$ & $(-2.10)$ & $(-1.84)$ & $(-0.41)$ & $(-2.49)$ & $(-0.13)$ \\
\hline \multirow[t]{2}{*}{ CDM_credits_landfill $x$ Year_2010 } & -0.001 & -0.001 & 0.001 & -0.020 & -0.005 & 0.002 \\
\hline & $(-0.35)$ & $(-0.20)$ & $(0.42)$ & $(-1.87)$ & $(-0.47)$ & $(0.94)$ \\
\hline \multirow{2}{*}{ CDM_credits_methane $x$ Year_2010 } & $-0.012^{* * *}$ & $-0.013^{* * *}$ & $-0.004^{* * *}$ & -0.008 & $-0.021^{* * *}$ & -0.000 \\
\hline & $(-5.35)$ & $(-4.80)$ & $(-4.08)$ & $(-1.59)$ & $(-4.23)$ & $(-0.36)$ \\
\hline \multirow[t]{2}{*}{ CDM_credits_wind $x$ Year_2010 } & 0.001 & -0.000 & 0.000 & $-0.021^{*}$ & -0.004 & $-0.005^{* * *}$ \\
\hline & $(0.26)$ & $(-0.06)$ & $(0.24)$ & $(-2.17)$ & $(-0.30)$ & $(-3.48)$ \\
\hline \multirow[t]{2}{*}{ CDM_credits_other $x$ Year_2010 } & -0.001 & -0.002 & -0.000 & -0.003 & -0.006 & -0.001 \\
\hline & $(-0.34)$ & $(-0.50)$ & $(-0.30)$ & $(-0.42)$ & $(-0.73)$ & $(-0.54)$ \\
\hline Obs. & 1116 & 1116 & 1116 & 1116 & 1116 & 1116 \\
\hline $\mathrm{R} 2$ & 0.41 & 0.35 & 0.56 & 0.54 & 0.89 & 0.60 \\
\hline AIC & -1081.5 & -789.2 & -2792.2 & 753.5 & 342.0 & -2264.7 \\
\hline DV mean & 3.89 & 3.76 & 3.96 & 2.12 & 3.23 & 4.26 \\
\hline
\end{tabular}

Note: All dependent variables are in logs. All independent variables are in logs except Year 2010 and GDP growth. Estimation by OLS. T-scores in parentheses.

Heteroskedasticity-robust errors. Constant and control variable coefficients omitted for presentation. 
Various additional checks were performed on these results. First, we examined the assumption, implicit until now, that each of the six outcomes can be reliably estimated by separate, independent equations. If the outcomes are not independent, then the errors across equations may be correlated (Zellner, 1962). This might be the case, for example, if an exchange rate shock altered remittance flows to Brazil in a way that changed inequality, unemployment and poverty levels simultaneously. As a robustness check, we estimated the six equations as a system using seemingly unrelated regression (SUR). SUR assumes that the errors of the individual equations are correlated and so improves the efficiency of the estimates relative to ordinary least squares (OLS) regression. Under SUR, the coefficient estimates are exactly the same as those under OLS (because the independent variables are the same across all six equations (Wooldridge, 2010)). The standard errors on the test variable increased in 5 out of the 6 equations under SUR, but so minimally (third decimal place or smaller) that we deemed them all but equivalent to the OLS estimates.

Second, we tried to improve the comparability of the regions in the control group to those in the treated group. We did this by dropping all regions in the states that did not receive a single CDM project (10 states, 230 regions) on the assumption that regions within states are more similar to each other than regions between states. In these tests, the magnitude of the coefficients diminish in all cases relative to the baseline estimates in Table3, yet all remain statistically significant. We also tried improving control group comparability in a different way. This was by randomly selecting an equally-sized sample of regions from the untreated group. In these tests, the estimated magnitudes also shrink but the overall results are similar to Table3. The results of these control group comparability tests for Theil, Gini, and Poverty are shown in the appendix.

Third, we tested the assumption that the outcome for the treated and control regions would have continued in parallel in the absence of the treatment, the parallel trends assumption (Wing, Simon, \& Bello-Gomez, 2018). We extended the panel backwards in time to include the year 1991, using census data for that year. We supposed that the same regions that had a CDM project during the 2004-2010 period had a project during the 1991-2000 period. They did not, but that is the point of the test. A significant coefficient on the interaction in this placebo test would indicate that something other than the treatment variable is influencing the outcome in the true test. Data were only available for Theil, Gini, and Poverty for the year 1991. Further, we had no data for GDP_growth, FDI_state, and Bolsa_spending for 1991 so those controls could not be included. In their place, we ran the same tests with region fixed effects. Five of the six specifications (see appendix) produce no evidence contradicting the 
main results reported above. The only exception is the Gini specification. That estimate implies that something other than CDM project activity reduced Gini inequality in the regions where CDM projects later appeared.

Fourth, we examined the decision to include only those CDM projects whose first credit issuance period began before or during 2010. The cut-off date of December 31, 2010 might exclude some projects that impacted the outcomes of interest. This would be the case if a project reduced unemployment in the construction phase during 2010, but only began to receive CER credits in 2011. To test this, we selected projects whose CER credit issuance period began before or during 2011 (154 projects) and before or during 2012 (169 projects), then re-ran the model. The results are given in Tables 8 and 9 in the appendix. They are very similar to the main results in Table 3 .

\section{Discussion and conclusions}

We find evidence that CDM project activity drove reductions in inequality, poverty and unemployment in Brazilian regions from 2000 to 2010, relative to Brazilian regions where no CDM projects were present. This result generally satisfies multiple robustness checks. We also find that methane, hydro and to a lesser extent biomass projects drove these reductions in particular, whereas wind, landfill and other project types did not. These findings are consistent with some prior research that has found that CDM project activity facilitates sustainable development gains (Du \& Takeuchi, 2019; Mori-Clement, 2019; Sutter \& Parreño, 2007) but inconsistent with other studies that have found limited or no impact on such outcomes (Crowe 2013; Mori-Clement \& Bednar-Friedl, 2019; Zhang \& Wang, 2011).

We interpret these results in terms of the FDI framework established in section 2. CDM project investment is a form of FDI or is closely related to it. General FDI that is sectorunspecific is expected to reduce unemployment and associated outcomes by creating demand for labour, and so, new jobs. However, FDI that flows specifically into primary and secondary sector activities does more to reduce unemployment than that which flows into tertiary sector activities, because it creates demand for low- and medium-skilled labour, and the workers suited to fill those jobs typically made up the unemployed part of the workforce prior to the arrival of the investment. Tertiary sector FDI by contrast creates demand for high-skilled workers, but does less to reduce unemployment because high-skilled workers tend to already have jobs. From this framework flows the inference that because methane, hydro, and biomass 
CDM projects reduced unemployment, they should have involved primary and secondary sector investment activities.

A caveat to this interpretation, and a limitation of our study, is that we were not able to systematically classify CDM projects in terms of economic sector or skill content from the available data. Obtaining such data and testing this idea explicitly would be a worthy direction

for future research. Another limitation concerns the uncertainties that the additionality principle and its implementation in the CDM project approval process create for the generation of CDM project data (see footnote 5 in section 3.2). We took extensive measures to select project records that capture real, on-the-ground project activity, but the administrative process behind the creation of the data was beyond our control.

\section{Conclusions and policy implications}

As governments continue to work towards a post-2020 agreement on international mitigation investment, developing country governments will be especially interested in ensuring that the agreement delivers real sustainable development outcomes of the kind studied here. The concerns of these governments could be partly addressed by incorporating concrete measures of unemployment, inequality, and poverty into the negotiation process and into the final text of the rulebook that implements a post-2020 mechanism. Stipulating new measurement and reporting rules for sustainable development outcomes would provide greater assurance that progress will be made on them. The text of the rulebook could require project developers and the CDM Executive Committee (or its replacement, or successor, as applicable) to report project activity in terms of a) economic sector, b) full-time equivalent jobs created, and c) the skill level of the jobs - and do so for all three, in line with a recognized economic activity classification system.

Should governments wish to go further than measurement and reporting, these metrics could further be used to broaden the incentives that project developers have to participate in a post-2020 mechanism. From the point of view of the climate, it does not matter whether a ton of GHG reduction occurs through a landfill project or a methane avoidance project. From the point of view of unemployment, inequality and poverty outcomes, it does matter, according to our findings. A post-2020 agreement that included systematic measurement, reporting, and verification procedures for those outcomes would set the stage for providing project developers with economic incentives to prioritize projects that advanced those outcomes. Such incentives would complement and not substitute for existing mitigation incentives. Such a provision in 
the post-2020 rulebook could be appealing to both developing and developed countries. It would also align the sustainable development language that all governments agreed to in past high-level agreements, with concrete incentives for delivering that aspiration.

\section{Acknowledgements}

The authors would like to thank two anonymous reviewers for their constructive suggestions, and Maeva Godemer for her contributions in the early stages of this research.

\section{References}

Alfaro, L., Kalemli-ozcan, S., \& Sayek, S. (2009). FDI, Productivity, and Financial Development. The World Economy. https://doi.org/10.1111/j.1467-9701.2008.01159.x

Allan, J. I., Antonich, B., Bansard, J., Luomi, M., \& Soubry, B. (2019). Summary of the Chile/Madrid Climate Change Conference: 2-15 December 2019 (Vol. 12). Retrieved from https://enb.iisd.org/climate/cop25/enb/

Almfrajiab, M., \& Almsafir, M. (2014). Foreign Direct Investment and Economic Growth Literature Review from 1994 to 2012. Procedia - Social and Behavioural Sciences, 129, 206-213.

Banco Central do Brasil. (2005). Censo de Capitais Estrangeiros.

Basu, P., \& Guariglia, A. (2007). Foreign Direct Investment, inequality, and growth. Journal of Macroeconomics, 29(4), 824-839. https://doi.org/10.1016/j.jmacro.2006.02.004

Bermejo Carbonell, J., \& Werner, R. A. (2018). Does Foreign Direct Investment Generate Economic Growth? A New Empirical Approach Applied to Spain. Economic Geography, 94(4), 425-456. https://doi.org/10.1080/00130095.2017.1393312

Bogliaccini, J. A., \& Egan, P. J. W. (2017). Foreign direct investment and inequality in developing countries : Does sector matter?, (June), 209-236.

https://doi.org/10.1111/ecpo.12098

Boyd, E., Hultman, N., Timmons Roberts, J., Corbera, E., Cole, J., Bozmoski, A., ... Liverman, D. M. (2009). Reforming the CDM for sustainable development: lessons learned and policy futures. Environmental Science and Policy, 12(7), 820-831. https://doi.org/10.1016/j.envsci.2009.06.007

Braden, S., Olsen, K., \& Verles, M. (2019). Assessment of sustainable development approaches for use in Article 6.

Cames, M., Harthan, R. O., Füssler, J., Lazarus, M., Lee, C. M., Erickson, P., \& SpaldingFecher, R. (2016). How additional is the Clean Development Mechanism? Analysis of the application of current tools and proposed alternatives. Freiburg im Breisgau.

Carbon Market Watch. (2017). Building blocks for a robust Sustainable Development Mechanism.

Chen, Z., Ge, Y., \& Lai, H. (2011). Foreign direct investment and wage inequality: Evidence from China. World Development, 39(8), 1322-1332. https://doi.org/10.1016/j.worlddev.2010.12.006

Crowe, T. L. (2013). The potential of the CDM to deliver pro-poor benefits. Climate Policy, 13(1), 58-79. https://doi.org/10.1080/14693062.2012.709080

Dirix, J., Peeters, W., \& Sterckx, S. (2016). Is the Clean Development Mechanism delivering benefits to the poorest communities in the developing world? A critical evaluation and proposals for reform. Environment, Development and Sustainability, 18(3), 839-855. https://doi.org/10.1007/s10668-015-9680-8 
Du, Y., \& Takeuchi, K. (2018). Can climate mitigation help the poor? Measuring impacts of the CDM in rural China (No. 1808). Kobe, Japan.

Du, Y., \& Takeuchi, K. (2019). Can climate mitigation help the poor? Measuring impacts of the CDM in rural China 2 . Journal of Environmental Economics and Management, 95(January 2017), 178-197. https://doi.org/10.1016/j.jeem.2019.03.007

Feenstra, R. C., \& Hanson, G. H. (1996). Globalisation, Outsourcing, and Wage Inequality (NBER Working Paper Series).

Hanson, G. H. (2003). What Has Happened to Wages in Mexico since NAFTA? NBER Working Papers, (March). Retrieved from http://ideas.repec.org/p/nbr/nberwo/9563.html

Herzer, D. (2008). The long-run relationship between outward FDI and domestic output: Evidence from panel data. Economics Letters, 100(1), 146-149. https://doi.org/10.1016/j.econlet.2007.12.004

Herzer, D., Hühne, P., \& Nunnenkamp, P. (2014). FDI and Income Inequality - Evidence from Latin American Economies, 18(4), 778-793. https://doi.org/10.1111/rode.12118

Iamsiraroj, S. (2016). The foreign direct investment-economic growth nexus. International Review of Economics and Finance, 42, 116-113.

Im, H., \& Mclaren, J. (2015). Does Foreign Direct Investment Raise Income Inequality in Developing Countries? A New Instrumental Variables Approach, 712-749.

Imran, S., Alam, K., \& Beaumont, N. (2014). Reinterpreting the definition of sustainable development for a more ecocentric reorientation. Sustainable Development, 22(2), 134144. https://doi.org/10.1002/sd.537

Jaumotte, F., Lall, S., \& Papageorgiou, C. (2013). Rising Income Inequality: Technology, or Trade and Financial Globalization\&quest;, 61(2), 271-309. https://doi.org/10.1057/imfer.2013.7

Jensen, N. M., \& Rosas, G. (2007). Foreign Direct Investment and Income Inequality in Mexico, 1990-2000. International Organization, 61(3), 467-487.

Kentor, J. (2001). The Long Term Effects of Globalization on Income Inequality, Population Growth, and Economic Development. Social Problems, 48(4), 435-455.

Khandker, S. R., Koolwal, G. B., \& Samad, H. A. (2010). Handbook on impact evaluation : Quantitative methods and practice. Learning (Vol. 1). World Bank.

Lechner, M., Rodriguez-Planas, N., \& Kranz, D. F. (2016). Difference-in-Difference Estimation by FE and OLS when there is Panel Non-Reponse. Journal of Applied Statistics, 43(11).

Makki, S., \& Somwaru, A. (2004). Impact of Foreign Direct Investment and Trade on Economic Growth: Evidence from Developing Countries. American Journal of Agricultural Economics, 86, 795-801.

Medeiros, M. (2016). World Social Science Report 2016 Income inequality in Brazil : new evidence from combined tax and survey data.

Michaelowa, A., \& Purohit, P. (2007). Additionality determination of Indian CDM projects. Can Indian CDM project developers outwit the CDM Executive Board?

Mori-Clement, Y. (2019). Impacts of CDM projects on sustainable development: Improving living standards across Brazilian municipalities? World Development, 113, 222-236. https://doi.org/10.1016/j.worlddev.2018.06.014

Mori-Clement, Y., \& Bednar-Friedl, B. (2019). Do Clean Development Mechanism Projects Generate Local Employment? Testing for Sectoral Effects across Brazilian Municipalities. Ecological Economics, 157(December 2017), 47-60. https://doi.org/10.1016/j.ecolecon.2018.10.011

Niederberger, A. A., \& Saner, R. (2005). Exploring the relationship between FDI flows and CDM potential. Transnational Corporations, 14.

Olsen, K. H. (2007). The clean development mechanism's contribution to sustainable 
development: A review of the literature. Climatic Change, 84(1), 59-73.

https://doi.org/10.1007/s10584-007-9267-y

Olsen, K. H., \& Fenhann, J. (2012). Sustainable development benefits of clean development mechanism projects A new methodology for sustainability assessment based on text analysis of the project design documents submitted for validation, 36(2008), 2819-2830. https://doi.org/10.1016/j.enpol.2008.02.039

Pandya, S. S. (2014). Democratization and FDI Liberalization, 1970 -2000. International Studies Quarterly, 58(3), 475-488.

Paulsson, E. (2009). A review of the CDM literature: From fine-tuning to critical scrutiny? International Environmental Agreements: Politics, Law and Economics, 9(1), 63-80. https://doi.org/10.1007/s10784-008-9088-0

Raveh, O., \& Reshef, A. (2016). Capital imports composition, complementarities, and the skill premium in developing countries. Journal of Development Economics, 118, 183206. https://doi.org/10.1016/j.jdeveco.2015.07.011

Schwartzman, S. (2003). Globalization, poverty, and social inequity in Brazil. Human Development.

Silveira Neto, R. da M., \& Azzoni, C. R. (2011). Non-Spatial Government Policies and Regional Income Inequality in Brazil. Regional Studies, 45(4), 453-461. https://doi.org/10.1080/00343400903241485

Sirohi, S. (2007). CDM: Is it a 'win-win' strategy for rural poverty alleviation in India? Climatic Change, 84(1), 91-110.

Suanes, M. (2016). Foreign direct investment and income inequality in Latin America: A sectoral analysis. CEPAL Review, 2016(118), 45-61. https://doi.org/10.18356/13c68e36en

Subbarao, S., \& Lloyd, B. (2011). Can the Clean Development Mechanism (CDM) deliver? Energy Policy, 39(3), 1600-1611. https://doi.org/10.1016/j.enpol.2010.12.036

Sutter, C., \& Parreño, J. C. (2007). Does the current Clean Development Mechanism (CDM) deliver its sustainable development claim? An analysis of officially registered CDM projects. Climatic Change, 84(1), 75-90. https://doi.org/10.1007/s10584-007-9269-9

Tsai, P.-L. (1995). Foreign Direct Investment and Income Inequality: Further Evidence. World Development, 23(3), 469-483. https://doi.org/10.1016/0305-750X(95)00136-Z

UNCTAD. (2011). Foreign direct investment, the transfer and diffusion of technology, and sustainable development.

UNFCCC. (2012). Clean Development Mechanism project cycle procedure.

Unger, M., Greiner, S., \& Krämer, N. (2019). The CDM Legal Context Post-2020 : Discussion Paper. Amsterdam.

United Nations General Assembly. (1987). Report of the World Commission on Environment and Development: Document A/RES/42/187. 96th Plenary Meeting. Retrieved from http://www.un.org/documents/ga/res/42/ares42-187.htm

Wetzel, D. (2013). Bolsa Família: Brazil's Quiet Revolution. The World Bank. Retrieved from http://www.worldbank.org/en/news/opinion/2013/11/04/bolsa-familia-Brazil-quietrevolution

Willem Te Velde, D. (2003). Foreign Direct Investment and Income Inequality in Latin America. Overseas Development Institue, 1-64.

Wing, C., Simon, K., \& Bello-Gomez, R. A. (2018). Designing Difference in Difference Studies: Best Practices for Public Health Policy Research. Annual Review of Public Health, 39(1), 453-469. https://doi.org/10.1146/annurev-publhealth-040617-013507

Wittman, H., \& Powell, L. J. (2015). Financing the agrarian transition ? The Clean Development Mechanism and agricultural change in Latin America, 47. https://doi.org/10.1068/a130218p 
Wooldridge, J. M. (2010). Econometric Analysis of Cross Section and Panel Data. Cambridge, MA, USA: The MIT Press.

Wooldridge, J. M. (2012). Introductory Econometrics (Vol. 120-121). South-Western Cengage Learning. https://doi.org/10.1016/j.jconhyd.2010.08.009

World Bank. (2005). Poverty Manual.

Zellner, A. (1962). An Efficient Method of Estimating Seemingly Unrelated Regressions and Tests for Aggregation Bias. Journal of the American Statistical Association, 57(298), 348-368.

Zhang, J., \& Wang, C. (2011). Co-benefits and additionality of the clean development mechanism : An empirical analysis. Journal of Environmental Economics and Management, 62(2), 140-154. https://doi.org/10.1016/j.jeem.2011.03.003

Zhang, K. H. (2001). How does foreign direct investment affect economic growth in China? Economics of Transition, 9(3), 679-693. 
Appendix A: Supplemental regressions

Table 5: Control group comparability regressions

\begin{tabular}{|c|c|c|c|c|c|c|}
\hline & Theil & Gini & Poverty & Theil & Gini & Poverty \\
\hline \multirow{2}{*}{ CDM_credits $x$ Year_2010 } & $-0.007^{* * *}$ & $-0.003^{* *}$ & $-0.016^{* * *}$ & $-0.008^{* * *}$ & $-0.003^{* *}$ & $-0.018^{* * *}$ \\
\hline & $(-3.83)$ & $(-3.17)$ & $(-4.13)$ & $(-3.62)$ & $(-2.99)$ & $(-3.92)$ \\
\hline \multirow[t]{2}{*}{ CDM_credits } & $0.004^{* *}$ & $0.002^{* *}$ & 0.004 & $0.005^{* *}$ & $0.002^{*}$ & $0.006^{*}$ \\
\hline & $(2.89)$ & $(2.74)$ & $(1.46)$ & $(2.71)$ & $(2.44)$ & $(2.02)$ \\
\hline \multirow[t]{2}{*}{ Year 2010} & $-0.241^{* * *}$ & $-0.130^{* * *}$ & $-1.079^{* * *}$ & $-0.225^{* * *}$ & $-0.130^{* * *}$ & $-1.050^{* * *}$ \\
\hline & $(-8.73)$ & $(-10.15)$ & $(-19.76)$ & $(-5.84)$ & $(-7.38)$ & $(-14.28)$ \\
\hline Observations & 886 & 886 & 886 & 544 & 544 & 544 \\
\hline $\mathrm{R} 2$ & 0.43 & 0.57 & 0.89 & 0.43 & 0.58 & 0.89 \\
\hline AIC & -883.1 & -2249.7 & 329.6 & -541.6 & -1407.6 & 191.4 \\
\hline DV mean & 3.87 & 3.95 & 3.06 & 3.86 & 3.94 & 2.96 \\
\hline
\end{tabular}

Note: All dependent variables are in logs. All independent variables are in logs except Year 2010 and GDP growth. Estimation by OLS. T-scores in parentheses.

Heteroskedasticity-robust errors. Constant and control variable estimates omitted for presentation. First three models exclude all regions in the states that did not have a single CDM project. Second three models use a randomly-selected sample of regions without a CDM project as the control group. 
Table 6: Placebo test results

\begin{tabular}{|c|c|c|c|c|c|c|}
\hline & Theil & Gini & Poverty & Theil & Gini & Poverty \\
\hline CDM_credits $x$ Year_2000 & $\begin{array}{l}-0.003 \\
(-1.81)\end{array}$ & $\begin{array}{c}-0.003^{* * *} \\
(-3.46)\end{array}$ & $\begin{array}{l}-0.002 \\
(-0.47)\end{array}$ & $\begin{array}{l}0.000 \\
(0.16)\end{array}$ & $\begin{array}{l}-0.000 \\
(-0.11)\end{array}$ & $\begin{array}{l}0.003 \\
(1.25)\end{array}$ \\
\hline CDM_credits & $\begin{array}{l}0.002 \\
(1.13)\end{array}$ & $\begin{array}{l}0.001^{*} \\
(2.23)\end{array}$ & $\begin{array}{l}-0.008^{*} \\
(-2.50)\end{array}$ & & & \\
\hline Year_2000 & $\begin{array}{c}0.081^{* * *} \\
(6.87)\end{array}$ & $\begin{array}{c}0.071^{* * *} \\
(12.01)\end{array}$ & $\begin{array}{c}-0.067^{* * *} \\
(-3.60) \\
\end{array}$ & $\begin{array}{l}0.101^{*} \\
(2.44)\end{array}$ & $\begin{array}{c}0.083^{* * *} \\
(3.63) \\
\end{array}$ & $\begin{array}{l}-0.074 \\
(-1.59)\end{array}$ \\
\hline Obs. & 1116 & 1116 & 1115 & 1116 & 1116 & 1115 \\
\hline $\mathrm{R} 2$ & 0.071 & 0.18 & 0.81 & 0.27 & 0.44 & 0.81 \\
\hline AIC & -1078.2 & -2651.3 & 158.8 & -2740.5 & -4288.2 & -2119.0 \\
\hline Micro-region FE & $\mathrm{N}$ & $\mathrm{N}$ & $\mathrm{N}$ & $\mathrm{Y}$ & Y & $\mathrm{Y}$ \\
\hline
\end{tabular}


Table 7: CDM projects selected by first credit issuance (101 projects only)

\begin{tabular}{|c|c|c|c|c|c|c|}
\hline & Theil & Theil work & Gini & Unemployment & Poverty & Income work \\
\hline \multirow[t]{2}{*}{ CDM_credits $x$ Year_2010 } & $-0.010^{* * *}$ & $-0.011^{* * *}$ & $-0.004^{* * *}$ & $-0.014^{* *}$ & $-0.019^{* * *}$ & 0.000 \\
\hline & $(-5.51)$ & $(-5.21)$ & $(-4.17)$ & $(-3.20)$ & $(-4.67)$ & $(0.31)$ \\
\hline \multirow[t]{2}{*}{$C D M$ credits } & $0.007^{* * *}$ & $0.008^{* * *}$ & $0.002^{* * * *}$ & 0.003 & $0.007^{* *}$ & $0.003^{* * *}$ \\
\hline & $(4.60)$ & $(4.92)$ & $(3.94)$ & $(1.06)$ & $(2.78)$ & $(3.59)$ \\
\hline \multirow[t]{2}{*}{ Year 2010} & $-0.196^{* * *}$ & $-0.245^{* * *}$ & $-0.117^{* * *}$ & $-0.640^{* * *}$ & $-0.982^{* * *}$ & -0.023 \\
\hline & $(-8.17)$ & $(-8.89)$ & $(-10.65)$ & $(-11.12)$ & $(-20.41)$ & $(-1.91)$ \\
\hline Obs. & 1116 & 1116 & 1116 & 1116 & 1116 & 1116 \\
\hline $\mathrm{R} 2$ & 0.39 & 0.34 & 0.55 & 0.53 & 0.89 & 0.59 \\
\hline AIC & -1081.4 & -789.3 & -2798.1 & 740.9 & 355.1 & -2265.4 \\
\hline DV mean & 3.89 & 3.76 & 3.96 & 2.12 & 3.23 & 4.26 \\
\hline
\end{tabular}

Note: All dependent variables are in logs. All independent variables are in logs except Year_2010 and GDP_growth. Estimation by OLS. T-scores in parentheses.

Heteroskedasticity-robust errors. Constant omitted for presentation. CDM_credits variable is constructed from only those projects that were actually issued credits before or during 2010 (101 projects rather than 147 in main results). 
Table 8: CDM projects selected by credit issuance period starting before or during 2011 (154 projects)

\begin{tabular}{|c|c|c|c|c|c|c|}
\hline & Theil & Theil work & Gini & Unemployment & Poverty & Income work \\
\hline \multirow{2}{*}{ CDM_credits $x$ Year_2010 } & $-0.011^{* * *}$ & $-0.012^{* * *}$ & $-0.004^{* * *}$ & $-0.013^{* * *}$ & $-0.022^{* * *}$ & 0.000 \\
\hline & $(-6.05)$ & $(-5.97)$ & $(-4.48)$ & $(-3.39)$ & $(-5.80)$ & $(0.10)$ \\
\hline \multirow[t]{2}{*}{$C D M \_$credits } & $0.006^{* * *}$ & $0.007^{* * *}$ & $0.002^{* * *}$ & 0.005 & $0.008^{* * *}$ & $0.003^{* * *}$ \\
\hline & $(3.99)$ & $(4.21)$ & $(3.42)$ & $(1.82)$ & $(3.33)$ & $(4.35)$ \\
\hline \multirow[t]{2}{*}{ Year 2010} & $-0.188^{* * *}$ & $-0.236^{* * *}$ & $-0.115^{* * *}$ & $-0.631^{* * *}$ & $-0.958^{* * *}$ & $-0.024^{*}$ \\
\hline & $(-7.67)$ & $(-8.39)$ & $(-10.22)$ & $(-10.90)$ & $(-19.74)$ & $(-2.01)$ \\
\hline Obs. & 1116 & 1116 & 1116 & 1116 & 1116 & 1116 \\
\hline $\mathrm{R} 2$ & 0.40 & 0.34 & 0.56 & 0.53 & 0.89 & 0.59 \\
\hline AIC & -1087.3 & -795.3 & -2800.3 & 741.9 & 340.3 & -2271.7 \\
\hline DV mean & 3.89 & 3.76 & 3.96 & 2.12 & 3.23 & 4.26 \\
\hline
\end{tabular}

Note: All dependent variables are in logs. All independent variables are in logs except Year_2010 and GDP_growth. Estimation by OLS. T-scores in parentheses.

Heteroskedasticity-robust errors. Constant omitted for presentation. CDM_credits variable includes projects with a crediting period starting before or during 2011. 
Table 9: CDM projects selected by credit issuance period starting before or during 2012 (169 projects)

\begin{tabular}{|c|c|c|c|c|c|c|}
\hline & Theil & Theil_work & Gini & Unemployment & Poverty & Income_work \\
\hline CDM_credits $x$ Year_2010 & $\begin{array}{c}-0.011^{* * *} \\
(-6.17)\end{array}$ & $\begin{array}{c}-0.012^{* * *} \\
(-6.12)\end{array}$ & $\begin{array}{c}-0.004^{* * *} \\
(-4.79)\end{array}$ & $\begin{array}{c}-0.014^{* * *} \\
(-3.93)\end{array}$ & $\begin{array}{c}-0.022^{* * * *} \\
(-6.05)\end{array}$ & $\begin{array}{l}0.000 \\
(0.18)\end{array}$ \\
\hline CDM_credits & $\begin{array}{c}0.006^{* * *} \\
(4.21)\end{array}$ & $\begin{array}{c}0.007^{* * *} \\
(4.41)\end{array}$ & $\begin{array}{c}0.002^{* * *} \\
(3.85)\end{array}$ & $\begin{array}{l}0.005 \\
(1.86)\end{array}$ & $\begin{array}{c}0.009^{* * * *} \\
(3.96)\end{array}$ & $\begin{array}{c}0.003^{* * *} \\
(4.43)\end{array}$ \\
\hline Year 2010 & $\begin{array}{c}-0.187^{* * *} \\
(-7.60) \\
\end{array}$ & $\begin{array}{c}-0.233^{* * *} \\
(-8.30) \\
\end{array}$ & $\begin{array}{c}-0.114^{* * *} \\
(-10.12) \\
\end{array}$ & $\begin{array}{c}-0.623^{* * *} \\
(-10.78)\end{array}$ & $\begin{array}{c}-0.954^{* * *} \\
(-19.77)\end{array}$ & $\begin{array}{l}-0.024^{*} \\
(-2.04) \\
\end{array}$ \\
\hline Obs. & 1116 & 1116 & 1116 & 1116 & 1116 & 1116 \\
\hline $\mathrm{R} 2$ & 0.40 & 0.35 & 0.56 & 0.54 & 0.89 & 0.59 \\
\hline AIC & -1089.6 & -799.6 & -2803.3 & 738.1 & 339.3 & -2273.0 \\
\hline DV mean & 3.89 & 3.76 & 3.96 & 2.12 & 3.23 & 4.26 \\
\hline
\end{tabular}

Note: All dependent variables are in logs. All independent variables are in logs except Year 2010 and GDP growth. Estimation by OLS. T-scores in parentheses.

Heteroskedasticity-robust errors. Constant omitted for presentation. CDM_credits variable includes projects with a crediting period starting before or during 2012. 